DOI: $10.21625 /$ resourceedings.v1i1.179

\title{
MULTI-DIMENSIONAL ASSESSMENT METHOD OF OPEN SPACES IN NEW COMMUNITIES/ LOW- MIDDLE INCOME HOUSING
}

\author{
TOWARD SOCIAL INTEGRATION \\ Mennatallah Tawfik ${ }^{1}$ Sara Ali ${ }^{2}$ \\ ${ }^{1}$ GUC ( German University in Cairo), 6th of October \\ ${ }^{2}$ Menia University, Cairo, Egypt
}

\section{Keywords}

Social segregation; social behavior; social integration; spatial structure;

\begin{abstract}
Rapid urbanization is considered today as a complex combination of what we have at the present and the shift that will happen in the future with many other social and economic forces. The mid-20th century and contemporary urban development create the new expanded urban areas that have the characteristics of fragmented integration cores towards the emergence of new centralities. The new built environment should have an intelligible special configuration to adapt to human agents and based on this insight, it is important to explore these propositions further and examine different ways to investigate the domain of urban spaces in new communities and its related social properties as urban spaces shouldn't compile one-dimensional demands.

This paper introduces some examples of open spaces in new communities' lowmiddle income housing that could be used to investigate how spatial patterns can influence social contribution. It also helps in analyzing the social factors which have an impact on the physical properties of the open spaces in these segregated urban patterns. The aim of this paper is to reach a multi-dimensional assessment method that could recover the open spaces that suffered from the absence of policies and regulations of urban planning and development. The study is introducing a methodology for empirically exploring and classifying the variables and attributes that define the physical and non-physical dimensions in open spaces by qualitative case study analyses to facilitate social cohesion and integration in the community. By comparing the results from the spatial and physical perspective, an assessment method will be reached at the end to formulate the new community potentials and to overcome the problems for more social integration.
\end{abstract}

\section{Introduction}

Many critiques of new communities have been raised in the last period that highlight problems in planning initiatives, the potential actions, and the stated goals of these communities. One of the main criticisms which are already acknowledged by the ministry of housing is that targeting a number of people to inhabit new communities aren't corresponding to the acquired goal to provide affordable housing for lower-income people and fulfilling their needs. 'Tadamun' highlights the most recent social housing law (Law No.33/2014) that states the national social housing program is based on providing affordable housing units in "areas identified by the Ministry of Housing in the governorates and in the New Urban Communities". It also allows for providing land plots for middle-income families in the NUCs, and to endorse, at least partially, the "social function of property". (Tadamun, 2015). 
The objectives of the new communities aren't only to afford social housing but also to cater social services and livable open spaces that can attract people and convey their presence to the spaces. Thus, New Cairo as a second generation community has been reevaluated as a capitalist city oriented for private sector developers, which led to many schemes of failure. Furthermore, Hafez, 2015 argued that new cities should target the social, economic, and urban objectives of a community in terms of creating independent communities. In the case of New Cairo, real estate investments in land use and focusing on luxurious housing is the major influence. There are about 34 closed luxury housing compounds in the city, seven of them are greater than 500 acres and the largest of these gatherings are Rehab 2220, Barwa 2020, Hyde Park 950, Imaar 904 acres, in addition to 27 residential communities ranging from 100 to 200 acres. The distribution of the aforementioned communities is clarified in Fig.(1).
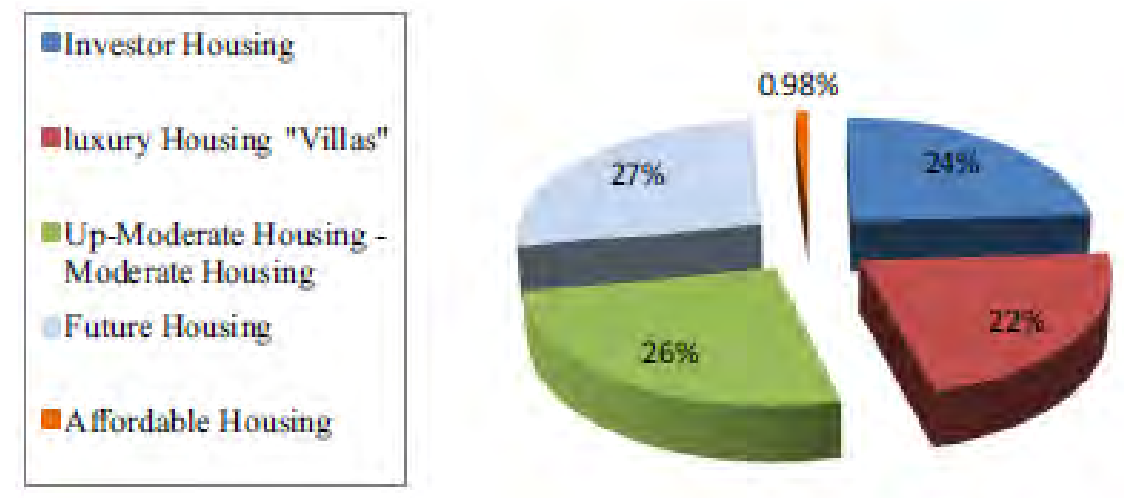

Fig. (1) Housing types, approximate ratios according to the general plan. Source: (Hafez, 2015)

Accordingly, the occurrences of affordable housing specifically the low-income housing; are not the foreseen ones and should be transformed in an urban and social sense. The public spaces should be questioned and investigated as the main property of urban development procedure and social interaction especially in such decline situation of dismal living conditions under the influence of real state power and economic liberalization which causes the livability to be hardly achieved. Thus, the paper explores and investigated the interrelation between the physical structure of New Cairo open spaces case studies and the socio-spatial interrelations.

\section{Literature Review}

The urban environment has gone through several stages. The first stage was was during the 1960s and founded by Kevin Lynch as he managed to detect the urban environment by reading and analyzing the optical images created by five basic components: paths, districts, landmarks, border edges, and nodes (Lynch,1984). In the 1980s, understanding the nature of the urban environment was developed to heavily rely on social dimensions, the presence of people and their needs, especially on activities performed within the environment that prompted urban planners and designers to change their point of view. Ashihara mentioned many attempts to clarify that spaces can be classified according to their degree of attractiveness of positive spaces which includes attracting elements and activities, and negative spaces that can be defined as space which repels its elements and activities (Ashihara, 1981).

Open spaces are always a reflection of social status, social behavior, sense of place and it resembles a state of mind that is interlinked to the spatial configuration of the physical built environment, political situation, and economic processes policies and regulation difficulties. Understanding the open spaces in the socio-spatial structure variables and measuring the urban complexity is helping in interpreting liberal Cairo's new communities, which have severe gaps in social integration and interaction. Hillier (2005) argued the preference for spatiality over space in social sciences, which means that space became nebulous and undeclared with the disjunction between the spatial discourses and there is a problem of space relatedness that must be addressed in urban design and architecture. Moreover, open spaces can be created intentionally or unintentionally and spaces can be formed with a time of use according to the function and activities that are related, and the community perception of space is responsible for transforming "space" into "Place" (Harrison and Dourish, 1996).

In addition to this, (Hillier and Hanson, 1984) introduce the space syntax theory that addresses the problem of space and its relatedness as it might be created by buildings densities with the clear dichotomy of its experimental side in relation to the people who live there. The theory of space syntax is investigating the powerful evidence of spatiality and its dependency on human beings that always begins with organizing and arranging the real spaces to understand the spatiality of human activity.

There are other arguments about the role of open spaces in maintaining social sustainability and if the sustainable. ElHiusseiny and Kessiba highlight the Knox argument about the sense of place that is socially constructed by the existential imperative of people to be there and to be self-organized in the space in relation to the material world. 
Space reflects the collective self-conscious structure of feeling, emotions, and moods that are evoked as memories of the place.

Thus, assessing sociability in different urban spaces in New Cairo's low-income housing areas to investigate in which manner spatial patterns can influence the social contribution is helping us understand the urban complexity dynamic, which apparently has failed to fulfill social integration. Sociability is an intangible aspect which is interrelated to physical and non-physical dimensions. Thus, Jehl (2002) measured sociability principles by monitoring the type of activity that happens in the space as three categories of activities that can occur in necessary activity, optimal activity, and social activity. These categories make people adopt what is known as "the perception of the space". Social activity is what produces the highest quality and goes further from other types of activities. It occurs spontaneously when the user resides in a certain place, and social activities associated with both the necessary and optional activities exist. The quality of social activity stimulates the number of users in the public space, which is transformed into a practice and presence in the space (Jehl, 2002).

Based on the above review, there are different principles and aspects with certain variables that interpret the interrelation between the physical structure and social interaction in the open spaces for more social integration. Starting with the physical dimension, and as seen in Fig (2), there are core aspects that affect the open spaces physical structure which are functional, morphological and spatial quality aspects. On the other hand, these aspects have interrelations with social integration variables that will be tackled in the case study analysis in the next part.

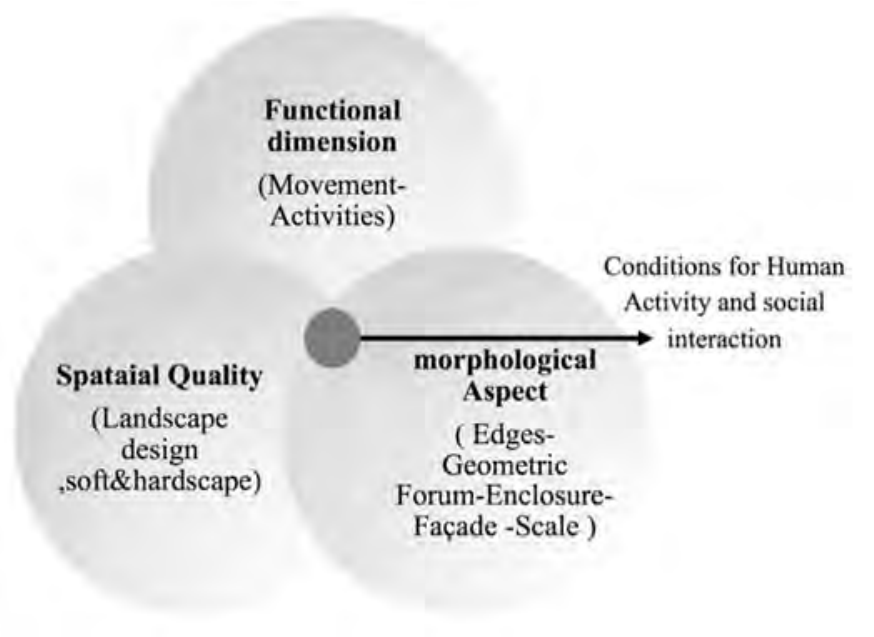

Fig. (2) Main aspects that affect the physical structure of open spaces Source: Authors

\section{Analysis of Open Spaces District No.3 Low-Income Housing Units in $5^{\text {th }}$ Settlement - New Cairo}

District No. 3 in $5^{\text {th }}$ settlement New Cairo is a governmental housing typology that is classified as low-middle income housing with different residential units' area; $64 \mathrm{~m} 2,77 \mathrm{~m} 2,79 \mathrm{~m} 2,94 \mathrm{~m} 2$. These housing units reflect the social transformation of the main owners' property to low-income people that are mainly renting the residential units and mostly are workers. This kind of problem negatively affected the urban situation, specifically the open spaces quality as they couldn't pay for maintaining the open spaces there and on the other side there are no other facilities, services, or even interaction within the spaces, thus it was necessary to understand the existing situation and what effects the social integration whether it is physical or non-physical aspects. 


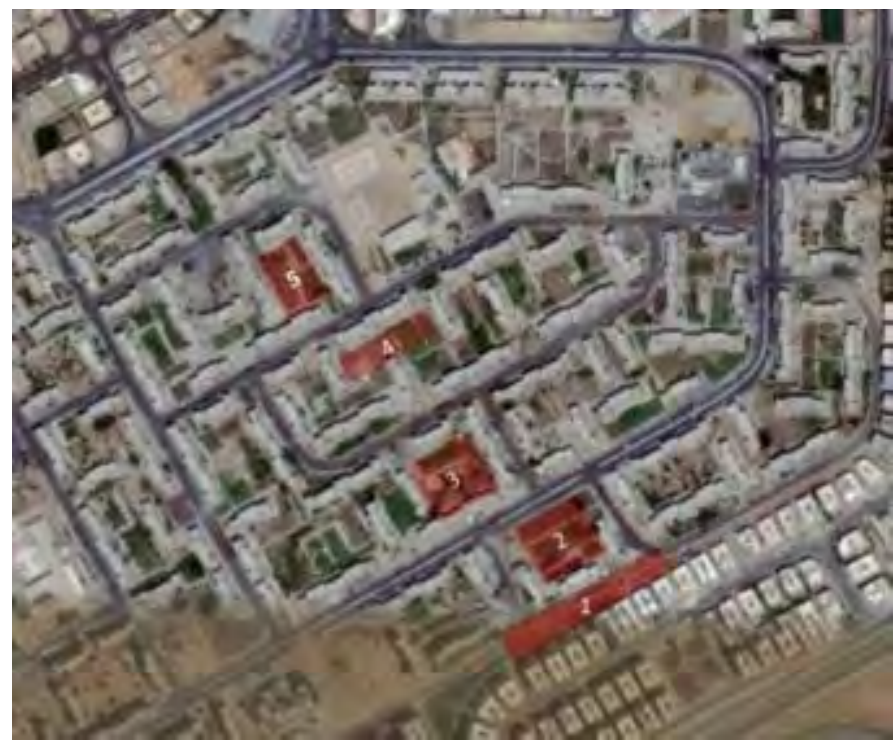

Fig. (3) Selected open spaces in District No.3 for analysis Source: Author

There are no organizational parties and governance support for the maintenance of the space greenery and the infrastructure provision or even communication with the residents.

\section{Interrelation between the Physical Structure and Social Processes in the Selection Open Spaces}

In order to identify and investigate the current situation of the open spaces in the low-middle income housing and find sustainable measures that should be widely considered, different variables that are conducted from the research and varied scholarly literature are highlighted and the interrelation was extracted to put the empirical study into practice and assess the selected open spaces.

(Table.1) illustrates the physical structure's main aspects: functional aspect, morphological aspect, spatial quality and the measures of social interactions with proposed interrelations between the former and later variables.

Table 1. Interrelations between the Physical Structure and Social Integration

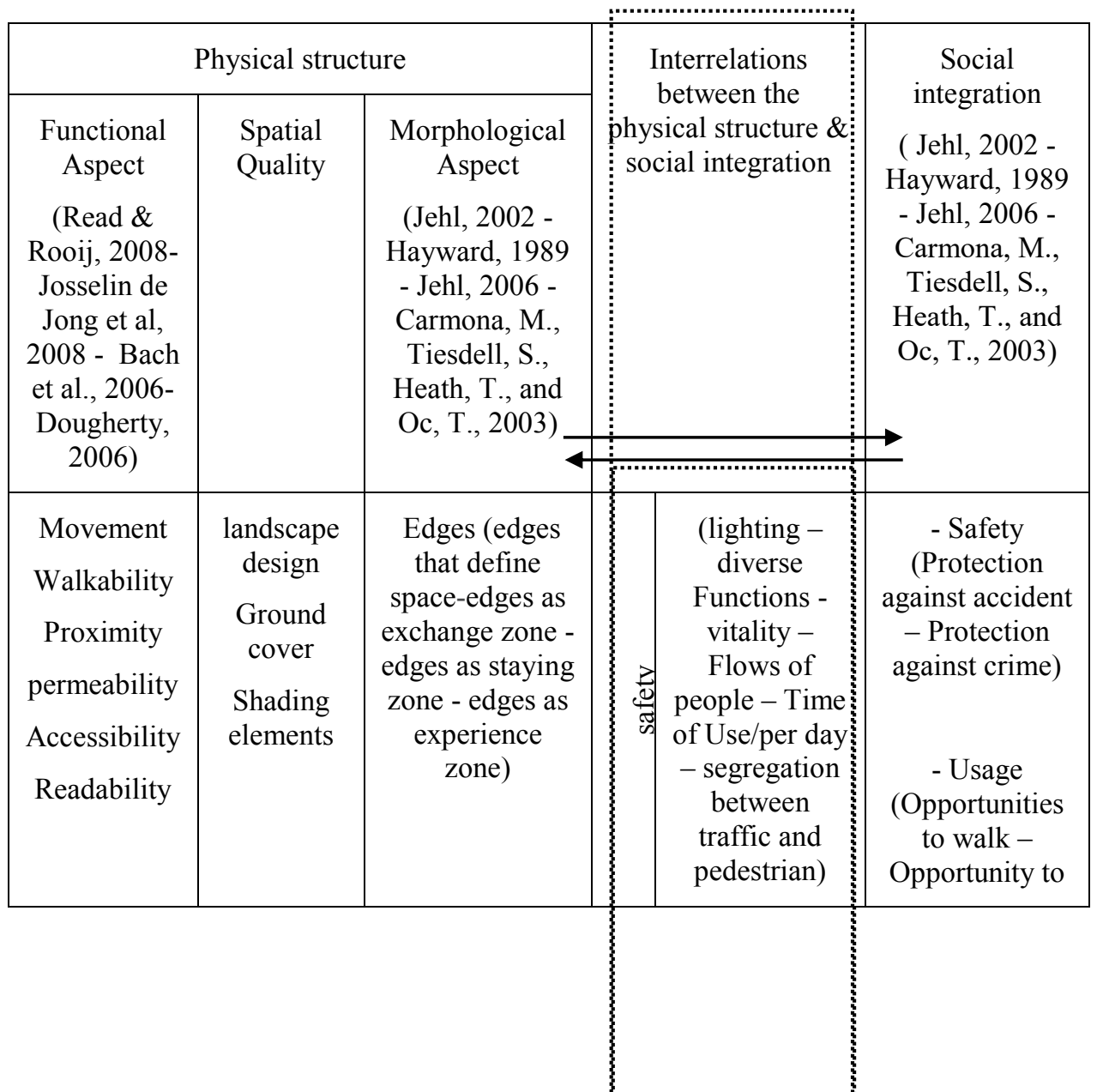


Mennatallah Tawfik, Sara Mohammed / Proceedings of Science and Technolgy

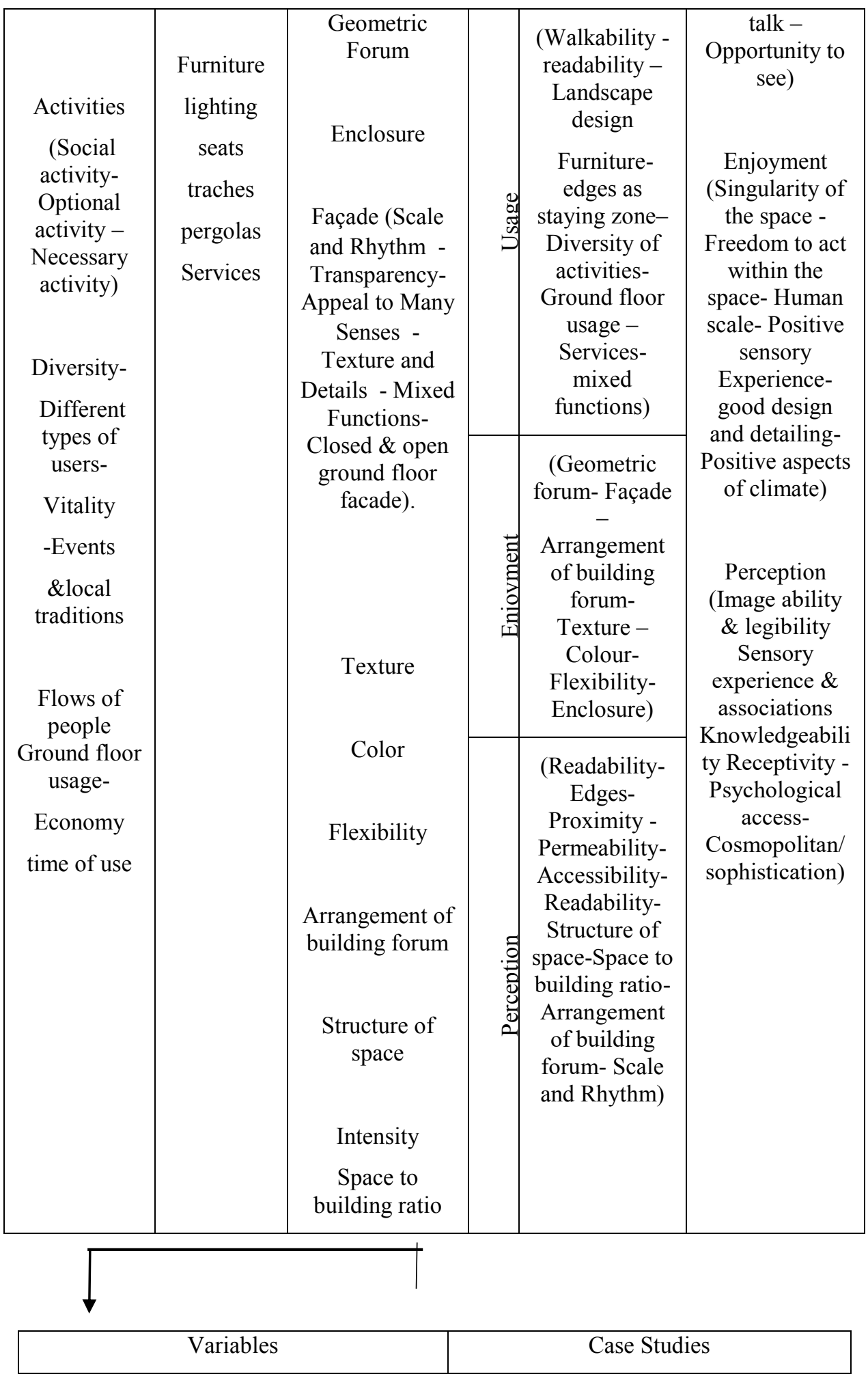

Source: Authors

\subsection{An Assessment Method to Evaluate the Open Spaces Social Interaction}

By means of the previous classification of the interrelated variables, there are descriptions of selected open spaces that could be used in further research to be obtained and studied. Based on observations and analysis, it was found that most of the open spaces are sharing the same scenarios with high similarities in the different measures. Table (2) summarizes the assessment classification method that was proposed based on each variable description and the measurement

factors

that

assist

each

variable. 
Table 2. The Assessment Classification Method of the Open Spaces in District N0.3

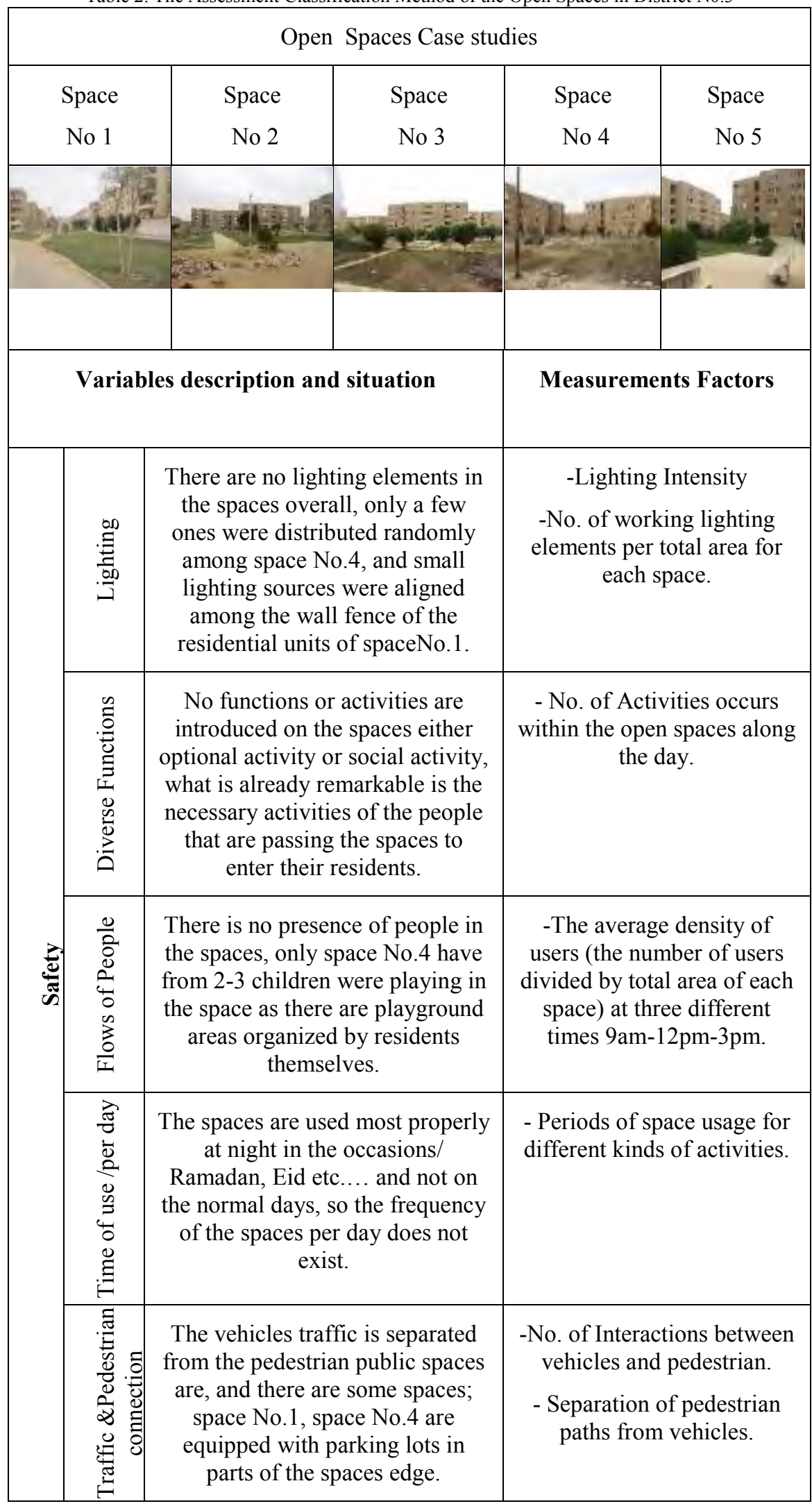




\begin{tabular}{|c|c|c|c|}
\hline & 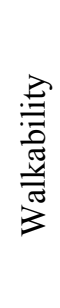 & $\begin{array}{c}\text { All the spaces are walkable but } \\
\text { not attractive for the residents to } \\
\text { walk through as there are no } \\
\text { appropriate paving materials or } \\
\text { texture. }\end{array}$ & $\begin{array}{l}\text {-The presence of pedestrian } \\
\text { zones. } \\
\text {-No steep slopes and stairs. } \\
\text {-Walkways average length. } \\
\text {-Walkways texture and } \\
\text { material. }\end{array}$ \\
\hline & 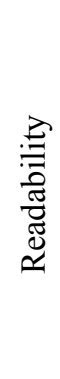 & $\begin{array}{l}\text { The spaces' readability and } \\
\text { intelligibility aren't } \\
\text { distinguishable from one to } \\
\text { another. }\end{array}$ & $\begin{array}{c}\text {-The open spaces distinctive } \\
\text { characters. } \\
\text {-The presence of important } \\
\text { landmarks distinguished } \\
\text { every space from the other. } \\
\text {-The presence of signs and } \\
\text { directions which gives a } \\
\text { sense of locality. }\end{array}$ \\
\hline & 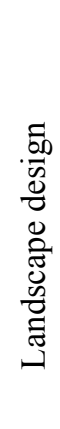 & $\begin{array}{l}\text { The landscape design is } \\
\text { unmaintained without actually } \\
\text { thinking of materials and } \\
\text { elements' suitability for the } \\
\text { different users' age, type, and } \\
\text { functions that could be attained in } \\
\text { the space. }\end{array}$ & $\begin{array}{l}\text {-No. of existing trees or } \\
\text { palms per } 100 \text { sq. m. } \\
\text {-\% of area shaded / semi- } \\
\text { shaded out of total space } \\
\text { area at noon } \\
\text {-Cleanliness Level. } \\
\text {-\% of green ground cover } \\
\text { out of total area for each } \\
\text { space }\end{array}$ \\
\hline & 莺 & $\begin{array}{l}\text { No adequate furniture in the } \\
\text { spaces and the seating elements } \\
\text { are clustered but in bad conditions } \\
\text { and not distributed appropriately } \\
\text { among the spaces. }\end{array}$ & $\begin{array}{l}\text {-No. of sitting places } \\
\text { (considering } 60 \mathrm{~cm} \text { width of } \\
\text { the seat for each person) per } \\
\qquad 100 \text { sq.m. } \\
\text {-Design of seating areas. } \\
\text { - Periodic maintenance rate. }\end{array}$ \\
\hline & $\begin{array}{l}\mathscr{D}_{0} \\
\underbrace{0}_{0} \\
\text { II }\end{array}$ & $\begin{array}{l}\text { The edges are defined by the } \\
\text { building clusters that surrounded } \\
\text { the open spaces, and parts of the } \\
\text { edges are facing the main streets } \\
\text { or defined by the streetcars } \\
\text { parking plots. }\end{array}$ & -Edges Scale and Rhythm \\
\hline & 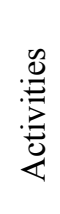 & $\begin{array}{l}\text { No activities are held in the } \\
\text { spaces, and there is just a } \\
\text { necessary movement to cross the } \\
\text { spaces to reach the residential } \\
\text { units. }\end{array}$ & $\begin{array}{l}\text { - No. and kinds of activities } \\
\text { held in the open spaces } \\
\text { (Necessary, Optional and } \\
\text { Social activities) }\end{array}$ \\
\hline & 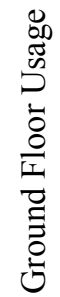 & $\begin{array}{l}\text { The ground floor interface is } \\
\text { restricted by district policies and } \\
\text { regulations to be used for any } \\
\text { commercial or marketing } \\
\text { activities, although there are very } \\
\text { few illegal car workshops that } \\
\text { mainly allocated in space N0.2. }\end{array}$ & $\begin{array}{l}\text { - Ground floor } \\
\text { Function(Varied- uniform) } \\
\text { - Ground Floor texture and } \\
\text { details (interesting- boring) } \\
\text {-Grond floor impact in many } \\
\text { senses( interactive- passive) }\end{array}$ \\
\hline
\end{tabular}




\begin{tabular}{|c|c|c|c|}
\hline & $\cdot \sum_{\substack{0 \\
\infty}}^{\infty}$ & $\begin{array}{l}\text { There are no amenities or services } \\
\text { in the open spaces }\end{array}$ & $\begin{array}{l}\text {-No. of kiosks, facilities } \\
\text { offer services to inhabitants } \\
\text { in the open spaces. }\end{array}$ \\
\hline \multirow{7}{*}{. } & 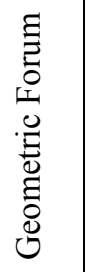 & $\begin{array}{l}\text { The basics geometric forms of all } \\
\text { the spaces are rectilinear, some } \\
\text { are in square proportions and the } \\
\text { others are in rectangles form, and } \\
\text { the spaces aren't proportionally } \\
\text { well-designed. }\end{array}$ & $\begin{array}{l}\text {-The relation between edges } \\
\text { and landscape design. }\end{array}$ \\
\hline & 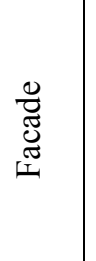 & $\begin{array}{l}\text { The facades are poorly distributed } \\
\text { among the spaces, unmaintained, } \\
\text { with sewage and sanitation } \\
\text { problems that left the facades in } \\
\text { very bad conditions. }\end{array}$ & $\begin{array}{l}\text {-Facades transparency level } \\
\text { (Open-closed). } \\
\text {-Facades Texture and } \\
\text { details. } \\
\text {-Facades rhythm. }\end{array}$ \\
\hline & 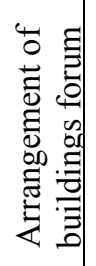 & $\begin{array}{l}\text { All the building that surrounds the } \\
\text { spaces is aligned linearly along } \\
\text { the edges. }\end{array}$ & $\begin{array}{l}\text {-The arrangement of } \\
\text { building ( Cluster- Linear- } \\
\text { Scattered) }\end{array}$ \\
\hline & 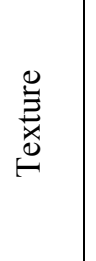 & $\begin{array}{l}\text { There is no texture specialty in } \\
\text { the spaces, what could be } \\
\text { distinguishable is the pavement } \\
\text { material from the greenery and } \\
\text { trees allocations. }\end{array}$ & $\begin{array}{l}\text { - Spaces elements and } \\
\text { surrounding buildings } \\
\text { external material impact on } \\
\text { walking pedestrians } \\
\text { (attractive/ boring - } \\
\text { good/poor materials ) }\end{array}$ \\
\hline & $\frac{\grave{0}}{0}$ & $\begin{array}{l}\text { No cheerful colors in the space } \\
\text { that visually affect the users and } \\
\text { give sort of attraction and } \\
\text { enjoyment to space }\end{array}$ & $\begin{array}{l}\text { - A number of colors used } \\
\text { intentionally in the design of } \\
\text { open spaces and the related } \\
\text { facades. }\end{array}$ \\
\hline & 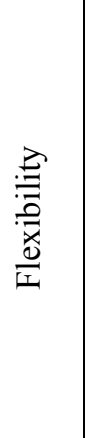 & $\begin{array}{l}\text { The open spaces are wide enough } \\
\text { to be equipped with different } \\
\text { functions and activities and to be } \\
\text { adopted with the flexibility to } \\
\text { have many activities and } \\
\text { installations but no potentials for } \\
\text { using the spaces. }\end{array}$ & $\begin{array}{c}\text {-No of fixed seats and } \\
\text { furniture. } \\
\text { - No of steep slopes and } \\
\text { stairs. } \\
\text { - Gross area of space in sq.m } \\
\text { to total area of surrounding } \\
\text { buildings. } \\
\text {-Allocation of trees, shrubs, } \\
\text { and palms. }\end{array}$ \\
\hline & 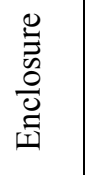 & $\begin{array}{l}\text { The open spaces have degree of } \\
\text { enclosure with the surrounding } \\
\text { buildings that go through the } \\
\text { edges as shown in Fig.(3) }\end{array}$ & $\begin{array}{c}\text { - The average height of two } \\
\text { opposite buildings to space } \\
\text { width. }\end{array}$ \\
\hline 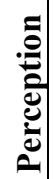 & 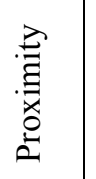 & $\begin{array}{l}\text { The spaces could reach easily } \\
\text { from the main streets, but the } \\
\text { internal spaces haven't internal } \\
\text { connectivity among them. }\end{array}$ & $\begin{array}{l}\text {-The relation between the } \\
\text { open spaces and main } \\
\text { streets, nodes and barking } \\
\text { lots. }\end{array}$ \\
\hline
\end{tabular}




\begin{tabular}{|c|c|c|}
\hline 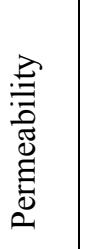 & $\begin{array}{l}\text { Open spaces permeability is } \\
\text { constant as there are no } \\
\text { consolidations between the spaces } \\
\text { and the users. }\end{array}$ & $\begin{array}{l}\text { - Infrastructure physical } \\
\text { barriers and its exposure to } \\
\text { the open spaces in terms of } \\
\text { reach. }\end{array}$ \\
\hline 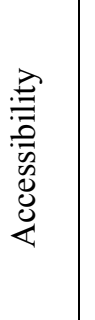 & $\begin{array}{l}\text { All the spaces are accessible for } \\
\text { the locals and the outsiders, } \\
\text { although the latter doesn't } \\
\text { perceive the spaces attractively } \\
\text { and easily accessible. }\end{array}$ & $\begin{array}{l}\text { - Total length of free edges } \\
\text { (to free parts of edges) that } \\
\text { users can enter the space } \\
\text { from it } \\
\text { - The distance between } \\
\text { nearest car parking lots and } \\
\text { spaces. }\end{array}$ \\
\hline 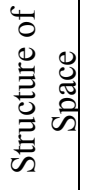 & $\begin{array}{l}\text { Space is structurally unorganized } \\
\text { without a specific order for } \\
\text { physical elements distribution. }\end{array}$ & $\begin{array}{l}\text { - The Presence of clear } \\
\text { visual characteristics that } \\
\text { define the open spaces. }\end{array}$ \\
\hline 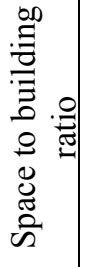 & $\begin{array}{l}\text { Spaces are enlarged incomparable } \\
\text { to the scale of the building which } \\
\text { the human feelings aren't } \\
\text { comfortably oriented, thus, } \\
\text { perceiving the space isn't valued } \\
\text { as well. }\end{array}$ & $\begin{array}{l}\text {-The average height of the } \\
\text { surrounding buildings to } \\
\text { space width. }\end{array}$ \\
\hline 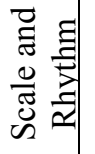 & $\begin{array}{l}\text { There is no scale or rhythm to } \\
\text { give the space certain order. }\end{array}$ & $\begin{array}{l}\text {-Landscape design rhythm. } \\
\text {-Edges and facades design. }\end{array}$ \\
\hline
\end{tabular}

Source: Authors

\section{Research Findings}

Based on the multifunction assessment method that was previously evaluated and discussed on selected case studies, the open spaces lack major principles and aspects of policies and regulations in the urban planning process, economic processes and service affordability, and maintenance problems in the physical structure itself as shown in Fig. (4) that causes unbalanced communities and social gaps between the other classes.

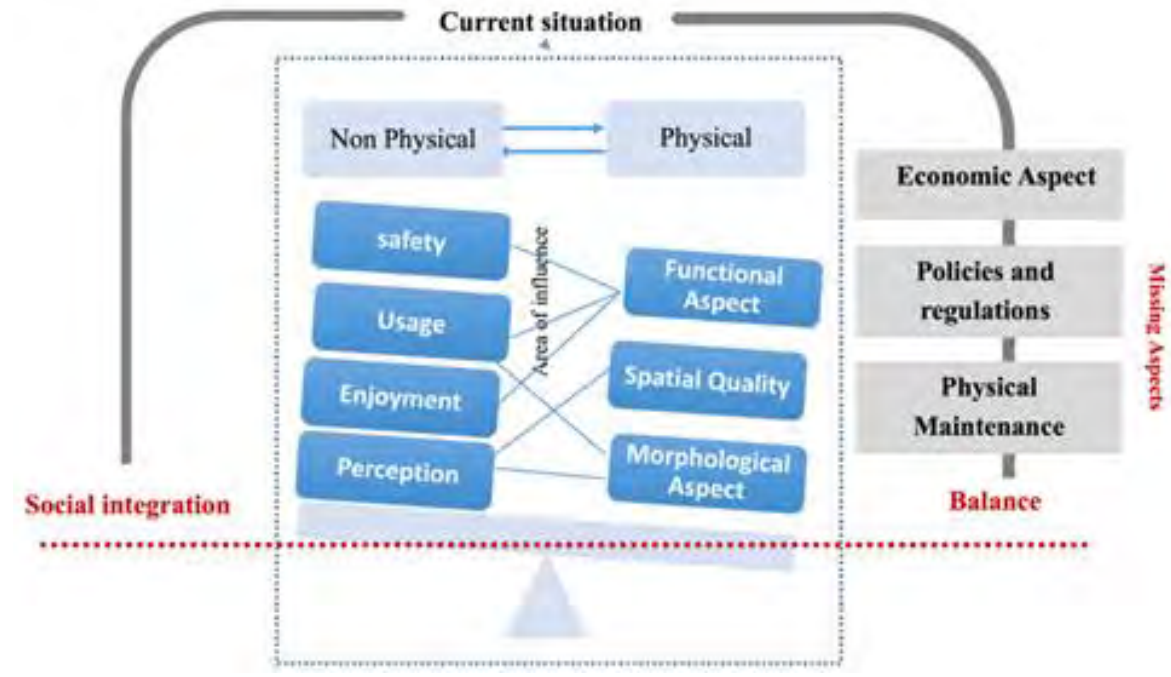

Fig. (4) Diagram Shows the Unbalanced Urban Situation of the Selected Study Area that Addressed by Social Segregation Source: Authors 


\section{Discussions and Conclusion}

Regarding the assessment method of the open spaces selected examples of the middle-low income housing in district No.03 New Cairo, it could be clearly explained and diagnosed that the studied areas of open spaces in these communities have potential but at the same time, there are many challenges and difficulties for providing services, activities and more social interaction due to the physical limitations and inappropriate living conditions. Physical structures are the factors that empower the open spaces and they should be effective in urban development and urban planning by paying attention to the social and economic processes that coincide with people's presence in the spaces.

In such new communities that have been transformed into commodities in the neo-liberal era, privatization should be considered and adapted to equally sustain the sociality in corresponding to the social and mental needs.

\section{Recommendations}

Finally, and after the case study analysis, the paper reached a set of recommendations related to several aspects: social, physical, economic, policies and regulation. The paper stresses on the key instrument of achieving social integration in open spaces of the new communities, which is the integration between all the previously mentioned aspects that should be supported by the local government through comprehensive integrated development plan that not only focuses on housing and the strategic infrastructure but also the interrelation between the physical infrastructure and the socio-economic processes in the context of urban development which guarantee the following:

\section{In the Economic Aspect}

- Utilization of ground floors for economic purposes in order to transform static edges into experience zones.

- Enhancing the community's productivity.

\section{Physical Structure:}

- Developing and sustaining urban infrastructure.

- Provide Services within the open spaces.

- Improve designed types of furniture which suits all community ages.

- Raising the level of safety and security by providing suitable lighting and guarantee the most of the day usages of the space.

- Promoting more balanced accessibility and connectivity.

\section{Policies and Regulations:}

- Framing laws that guarantee the continuity of maintenance of urban spaces.

- Improving the cooperation between community and local governance.

- Evolving community in formulating the vision of improving the urban environments

\section{References}

1. Hafez, R. (2015)," New cities between sustainability and real estate investment: A case study of New Cairo city ". HBRC Journal. Retrieved from: http://dx.doi.org/10.1016/j.hbrcj.2015.03.001.

2. Harrison and Dourish, (1996), "Re-Placing Space: The Roles of Place and Space in Collaborative Systems", Rank Xerox Research Centre Cambridge Lab (EuroPARC). Retrieved from http://www.cc.gatech.edu/ keith/classes/ubicomplexity/pdfs/crit/harrison-place-space.pdf .

3. Ashihara, Yoshainbou, (1981), "Exterior Design in Architecture", Van Nostrand Reinhold Company, USA, Page: 25.

4. Carmona, M. (2003). Public Places- Urban Spaces ( $1^{\text {st }}$ ed.). New York: Architectural Press.

5. Carmona, M., Tiesdell, T. H., \& Oc, T. (2010). Public Places- Urban Spaces: The Dimensions of Urban Design (2nd ed.). New York: Architectural Press.

6. GEHL, J, (2006), New city life, Copenhagen, Danish Architectural Press.

7. GEHL, J" Cities for People", (2010), Island Press, Washington 1 Covelo 1 London, page 21.

8. Hillier, B. and Hanson, J. (1984) The Social Logic of Space. Cambridge, Cambridge University Press.

9. Lynch, K., (1984), Good City Form, Cambridge, Massachusetts: MIT Press.

10. El-Hiusseiny .and Kessiba, (2012), "Challenges of Social Sustainability in Neo-liberal Cairo: Re- questioning the role of public space”, in Asia Pacific International Conference on Environment-Behaviour Studies, Mercure Le Sphinx Cairo Hotel, Giza, Egypt, 31 October 2 November, pp.739-749.

11. GEHL ARCHITECTS APS, (2002), "Public Spaces and public life. city of Adelaide", Available at http://www.adelaidecitycouncil.com [accessed December 6, 2016].

12. Tadamun. (2015) "Egypt's New Cities: Neither Just nor Efficient", Retrieved December 3, 2016, from http://www.tadamun.info/2015/12/31/egypts-new-cities-neither-just-efficient/?lang=en\#.WEshHKJ97_Q . 